\title{
TEMPERANCE AND ALCOHOL HISTORY IN SPECIAL COLLECTIONS AND UNIVERSITY ARCHIVES AT THE RUTGERS UNIVERSITY LIBRARIES
}

BY RONALD L. BECKER

\section{Ronald L. Becker is the head of Special Collections}

Special Collections and University Archives (SC/UA) at the Rutgers University Libraries holds significant collections, both printed and manuscript, documenting the history of the temperance movement and prohibition in New Jersey and nationally. These range from children's chapbooks containing warnings to juveniles about the evils of liquor, to the proceedings of large organizations dedicated to ending liquor consumption altogether.

\section{Printed Materials}

The Rare Book and Sinclair New Jersey Collections contain more than 500 books and periodicals relating to temperance, dating as far back as I75I. These collections represent the largest gathering of primary source materials on New Jersey history and culture and one of the largest regional-history libraries in the nation. As New Jersey serves as a barometer of its reaction to national trends and movements, the collection is used by students and scholars investigating many subject areas from throughout the country. Although there are works about all aspects of liquor consumption published throughout the United States and abroad, the heart of the collection is in its thorough documentation of the temperance movement in the state.

The best description of the printed works is found in Donald A. Sinclair's Demon Rum: A Bibliograpby of Publications about Liquor and New Jersey, 1779-1932 (New Brunswick, NJ: Rutgers Special Collections and University Archives, I996). In it, he describes hundreds of publications (books, pamphlets, broadsides, periodicals, and newspapers), including the first printed work on the topic issued by a New Jersey press: Anthony Benezet's The Mighty Destroyer Displayed, in Some Account of the Dreadful Havock Made by the Mistaken Use as 


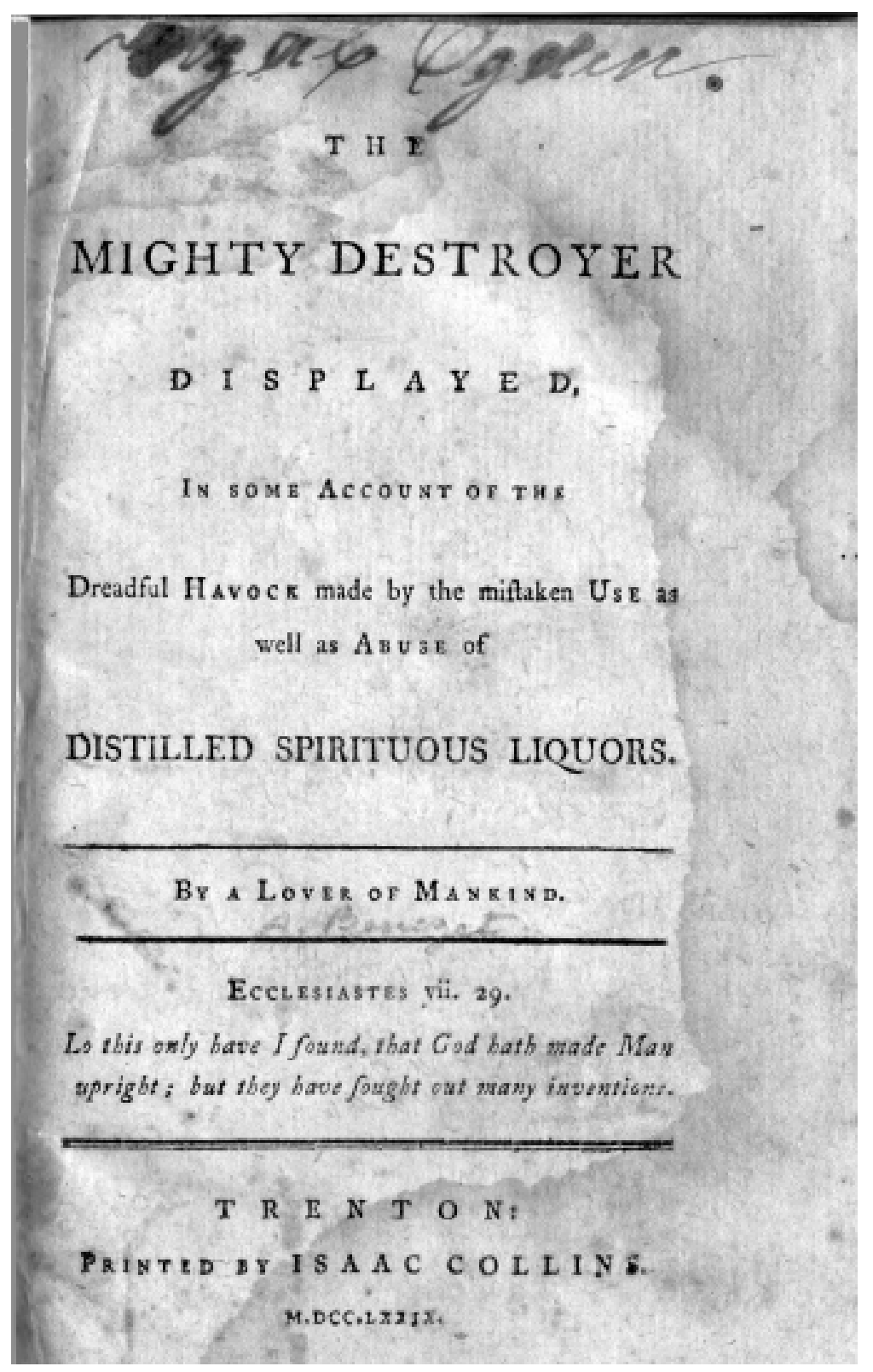

Figure 6.I [Benezet, Anthony]. The Mighty Destroyer Displayed, In Some Account Of The Dreadful Havoc Made By The Mistaken Use As Well As Abuse Of Distilled Spirituous Liquors (Trenton, 1779) (from Special Collections and University Archives) 
Well as Abuse of Distilled Spiritous Liquors by a Lover of Mankind, printed in Trenton by Isaac Collins in I779. The library also holds an earlier edition, published in Philadelphia by Joseph Crukshank in 1774. Such titles as Serious Thoughts on the Traffic in Distilled Spirituous Liquors: and on the Customary Use of that Article as a Common Drink; Addressed to the Particular Attention and Weighty Consideration of the Seriously Disposed of all Denominations of Professing Christians and Pbilantbropists / by a Well-wisher to the Family of Mankind (Burlington: David Allinson, I8I I) were available to concerned Jerseyans of the nineteenth century and are available today to researchers at Rutgers, The State University of New Jersey.

New Jersey abounded with organizations formed to promote temperance, liquor control, treatment of alcohol abusers, and prohibition. Although some were branches of national organizations, many were "homegrown," beginning with the Sober Society in Allentown, founded in 1805, whose manuscript articles of association were published in the New Jersey Historical Society Proceedings in 1929. By the end of the nineteenth century, dozens of municipalities and the majority of the counties sported these associations. In addition to the numerous county temperance societies, other flourishing nineteenth-century organizations that were centered around espoused temperance doctrines included the Atlantic Highlands Association; Bloomfield Temperance School; Bordentown Prohibition Club; Bridgeton City Temperance Alliance; Bridgeton Citizens Temperance Executive Committee; Daughters of Temperance; Eleventh Ward Prohibition Club of Newark; Evesham Association for Discouraging the Unnecessary Use of Ardent Spirits; Flemington Temperance Reform Club; Morristown Temperance Society; New Jersey Sabbath Union; New Jersey State Inebriate Asylum Association; New Jersey State Temperance Alliance; New Jersey State Temperance Society; Newark Pastoral Association; Readington, Tewksbury, and Lebanon Society for the Suppression of Vice and Immorality, and for the Promotion of Virtue and Good Morals; St. James Total Abstinence Society of Newark; Society for Suppressing the Illegal Sale of Intoxicating Liquor and Gambling in Hoboken; and Somerville and Raritan Anti-Saloon Republican League. The Rutgers collection includes the constitutions and bylaws, minutes and proceedings, discourses, broadsides, and other publications of these and related organizations.

New Jersey also had county and municipal chapters of state and national societies, including numerous divisions of the Sons of Temperance of North America, Templars of Honor and Temperance of New Jersey, Washington 
NEW JERSEY STATE INEBRIATE ASYLUM. VINELAND, N. J.

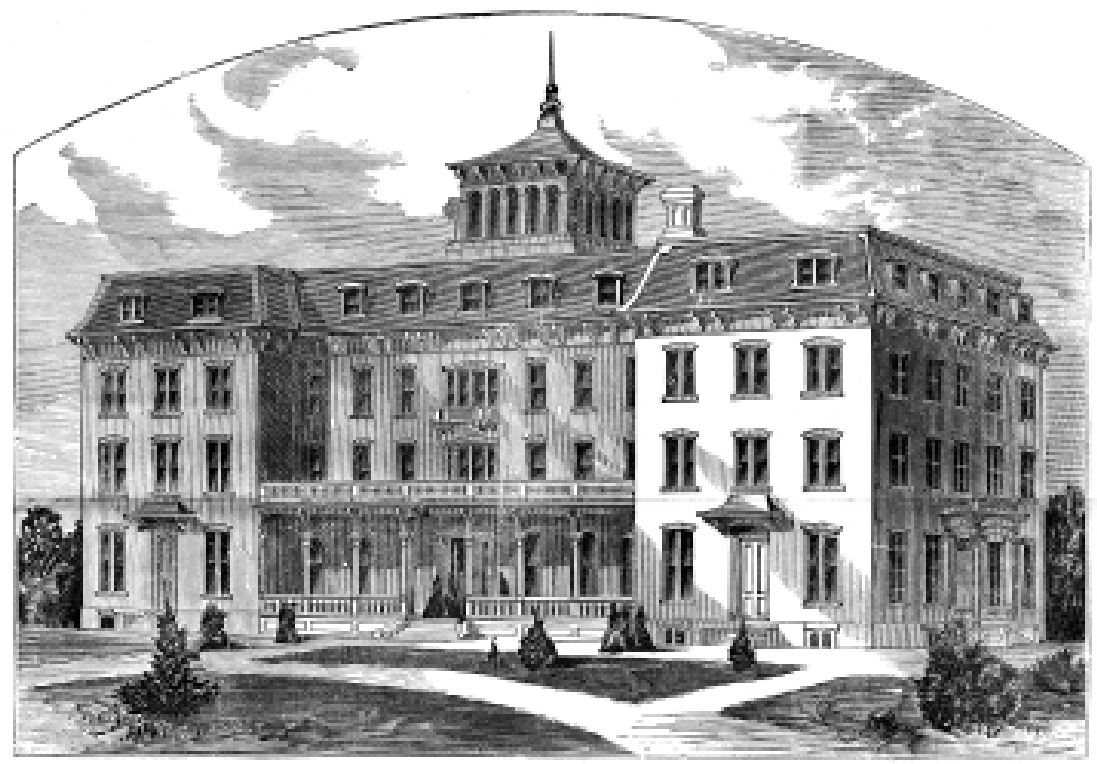

BOARD OF DIREOTORS.

MARCIUS WILASON, Presitent, PHILIP SNYDER, Secretarf. H.
Gen, W, T. Sewne,
Grobar B. Coons, Hon. E. A. Аnask,

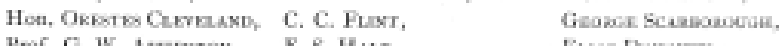

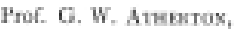
F. \& Hatx,
Euss Dhuriery,
Hon. Jaxes Lovihrax,
Gez. Jas. F. Rers.isi,
Hon. Jayes H. Niscos.

H. N. GREENE, Treasuret.

THOSLAS W. CONWAY, Suparintendent.

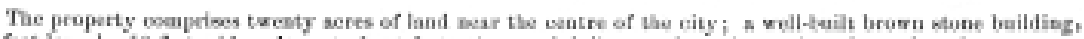

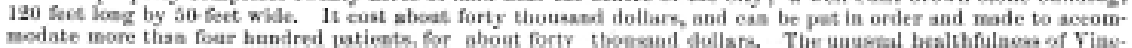

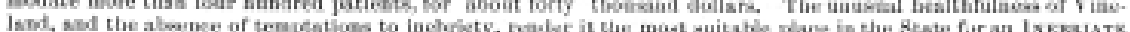

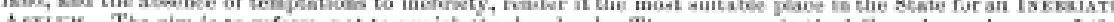

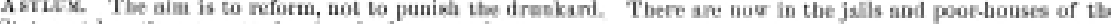

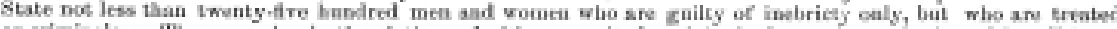
as eriminale. They are simpiy the vietims of enther sequind or intierited appecite, of boch, and it will be as much to the eredit of our slatemanship as to that of our huinanity, to peovile a plsce foe their proper treatmeat sepante sind apart frove eommon erinalnals.

Figure 6.2 Is New Jersey in Need of a Reformatory for Inebriates? (I879) (from Special Collections and University Archives) 
Temperance Benevolent Society, and Woman's Christian Temperance Union. No remote corner of New Jersey was spared these organizations, which included chapters in urban and rural areas of the state from the large cities in the north to hamlets such as Upper Pittsgrove Township in the south.

There were also many serial publications devoted entirely or largely to temperance. Examples at Rutgers include such titles as New Jersey Good Templar (Vineland) and New Jersey Weekly Visitor, and Temperance Sentinel (Trenton). Temperance and alcohol abuse became a favorite theme for the nineteenthcentury pulpit, by ministers of many denominations. The Rutgers collection includes printed sermons given throughout New Jersey. Court cases also abounded, and these too are well documented in printed proceedings. These include criminal and civil trials related to the granting of licenses and to disorderly conduct and worse crimes due to drunkenness, illegal sale of liquor on the Sabbath, and other "indictable nuisances." The New Jersey State Legislature, the governor, and various state-appointed commissions were not to be outdone; numerous laws and printed speeches and messages are available for research in the collection.

By the twentieth century, the printing presses slowed down their production of temperance-related publications, but with the coming of National Prohibition (1919-1933) there was a new round of both proand anti-prohibition and temperance pamphlets, broadsides, and serials put out by organizations (both public and private) and individuals. Thus, every aspect of the topic, from the dawn of the American Revolution to the present, is covered in Special Collections and University Archives at Rutgers.

\section{Manuscripts: Organizational Records}

Manuscript materials include both the records of temperance organizations and the papers (especially diaries) of those involved in the movement, many of whom were women. New Jersey organizational records include those of the Florence Mission in New Brunswick; the Young Men's Father Matthew Total Abstinence and Benevolent Society in Elizabeth; the New Brunswick Total Abstinence Society; the Sea Bright Band of Hope; the Temperance League of New Jersey; the Temperance Society of Flanders New Jersey; the Lebanon chapter of the Woman's Christian Temperance Union (WCTU); and the WCTU's Bergen, Mercer, Middlesex, and Monmouth County chapters. 


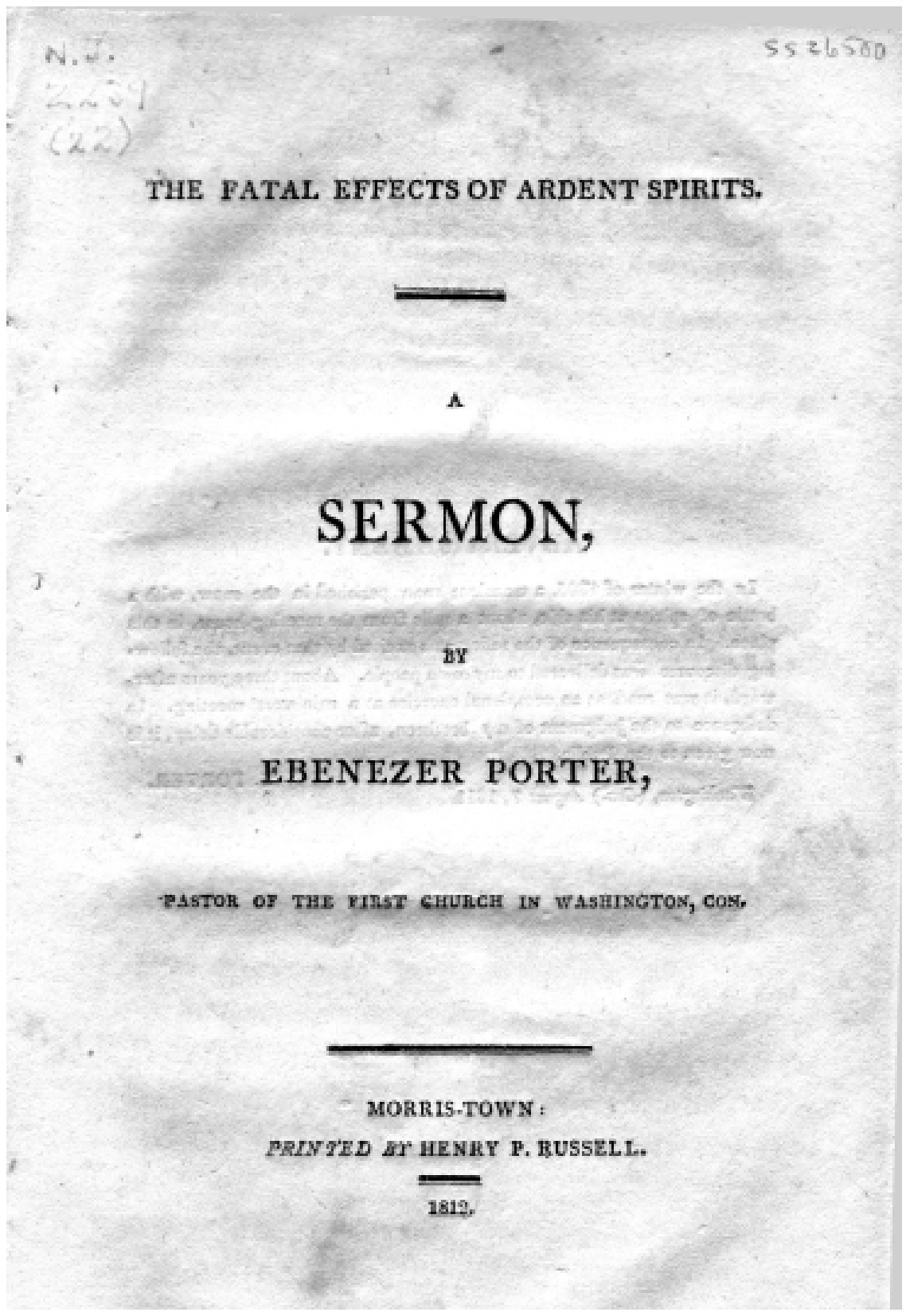

Figure 6.3 Porter, Ebenezer. The Fatal Effects of Ardent Spirits. A Sermon (I8I2) (from Special Collections and University Archives) 
The Florence Mission was founded in 1889 and was associated with the Woman's Christian Temperance Union; it promoted temperance, evangelism, the rehabilitation of "human derelicts," nightly gospel meetings, and a Sabbath school. The collection (I889-1898) consists of accounts, a journal, an inventory of furnishings, historical notes, clippings, and correspondence, much of which is to Ellen S. Kilburn, the mission's general superintendent.

The records of the Young Men's Father Matthew Total Abstinence and Benevolent Society consist of a record book dated I886-I9I0, which includes minutes, a membership list, financial accounts, and lists of officers, committees, sick members, and those who resigned.

The New Brunswick Total Abstinence Society's minute book of I836 contains minutes of regular and executive committee meetings, a constitution, and a temperance pledge signed by eighteen society members.

The Sea Bright Band of Hope's records date from I887-I89I and include minutes, membership dues accounts, and members' pledges of abstinence from the use of alcoholic beverages, tobacco, and profanity.

The Temperance League of New Jersey's records contain the superintendent's reports from I95I until I954. The Temperance Society of Flanders New Jersey is represented by a microfilm copy of its proceedings from 1835 to 1844 .

The Woman's Christian Temperance Union records are represented by the Lebanon chapter's minutes from 1939 until I953, together with clippings, certificates, and a program for a spring institute to be held in Hunterdon County. Also included in the collection are records of the Bergen, Mercer, Middlesex, and Monmouth chapters.

The Bergen County records consist of minutes of executive committee meetings, monthly meetings, annual conventions, and spring institutes, I896I909 and 1924-1940, accompanied by minutes of the monthly meetings, I892-I908 and I943-I948, of the Hackensack WCTU.

The Mercer County records include minutes, I892-1940, of executive board meetings, spring institutes, and annual conventions, accompanied by records of the Trenton No. I WCTU: a constitution and pledge book, I876-ca. I906; minutes, I876-I896, I90I-I93I, and I94I-I952, of regular and executive committee meetings; minutes, I90I-I902, of the Y branch; a membership list, 1940-1967; a typescript history (covering 1876-194I); and a scrapbook, I873I98I. Also present are a scrapbook, I93I-I932, with clippings relating to two 


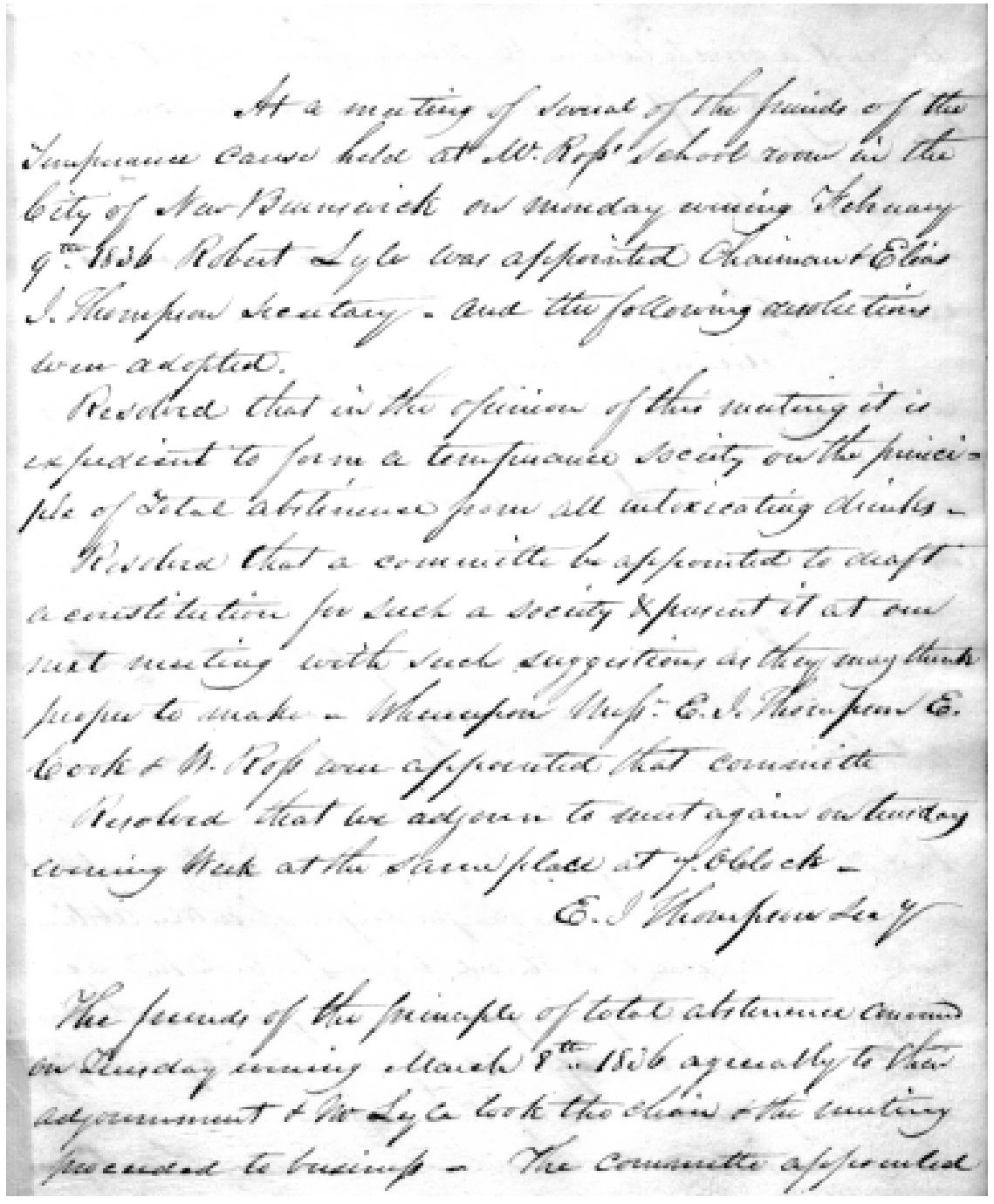

Figure 6.4 Minutes from the first meeting (March 8, 1836) of the New Brunswick Total Abstinence Society: "Resolved that in the opinion of this meeting it is expeditious to form a temperance society on the principle of total abstinence from all intoxicating drinks" (from Special Collections and University Archives) 
Trenton unions (Trenton No. I and Willard); minutes, I9I I-I9I3, of meetings of the Anna M. Robbins WCTU (of Trenton); a membership list and treasurer's reports, 1942-1960, of the Hillcrest WCTU (of Trenton); minutes, 19691974, of the Iota Sigma of Ewing WCTU; and a constitution and minutes, I885-I89I, of regular and executive committee meetings of the Citizen's League of the City of Trenton, a temperance organization.

The Middlesex County records include minutes of conventions, I886193I. Also included are meeting minutes, I908-I9I5 and I923-I948; treasurer's accounts, I897-I903 and 1936-1942; and scrapbooks of press clippings, 1930-1940, of the New Brunswick WCTU (known after late I 923 as the Anna D. Perrine WCTU); minutes, I918-I922, of the Sayreville WCTU; scrapbook of press clippings, 1929-1930, pertaining to the Metuchen WCTU; printed matter (chiefly programs and annual calendars of events), 1928-1940, pertaining to the state WCTU and the WCTU in Middlesex County, as well as to the New Jersey Committee on the Cause and Cure of War; and other printed matter, consisting primarily of temperance publications issued by the national WCTU.

Finally, the Monmouth County records include minutes, I893-1930, of executive committee meetings, annual conventions, spring institutes, and the like, as well as treasurer's records, I893-I9I I.

\section{Manuscripts: Personal Papers}

In its manuscripts division, Special Collections and University Archives has many collections of the papers of individuals and families. Within these collections are diaries, correspondence, documents, and related materials. Temperance was on the minds of several of those represented, including in the diaries of Samuel Allinson, Alfred H. Buck, Stephen Sylvester Day, Lucia Grieve, Obadiah Howell Hazard, Harriette Smith Kidder, Sarah Coryell Shaw, Isaac Webster, and Abram Bergen Wyckoff.

Residing in Burlington and Yardville, Samuel Allinson was an esteemed Quaker philanthropist, active in temperance as well as in antislavery and prison-reform work. He is known as being the prime mover for the establishment of reform schools in New Jersey. Rutgers has his diary, which is particularly detailed for the period between I824 and I829.

The library holds the Civil War journal of Alfred H. Buck (a native of Salem County), written from I862 though the end of I864. It consists of 
his detailed record of camp, hospital, and garrison life as a sergeant in Company $\mathrm{H}$ of the Twelfth New Jersey Infantry who was wounded at the battle of Gettysburg. An interesting feature of the diary is Buck's attendance at two temperance meetings and occasional notes about drunkenness that he observed in his surroundings.

The diary of Stephen Sylvester Day dating from I895 to I932 details his active business, family, and personal life in Essex and Morris counties. Among other things, he was active in temperance activities and Methodist Church affairs.

The Lucia Catherine Graeme Grieve papers date from I878 to I937. She was a student, teacher, lecturer, farmer, poet, and homemaker whose diaries include material about temperance and Methodist activities in Ocean Grove and Freehold as well as in other locations in the United States and abroad.

Obadiah Howell Hazard attended the Princeton Theological Seminary and became pastor of the Presbyterian churches at Freedom Plains and Highland Falls, New York. His diary contains a temperance pledge he made in 1873 .

Harriette Smith Kidder was a teacher and principal at the Worthington Female Seminary in Ohio. She was married to a minister and editor of Methodist Sunday school publications and lived in Newark, Madison, and Ocean Grove as well as Illinois and New York City. Her diary spanning I844 to 1902 includes information on her interest in temperance and her theological, moral, and social concerns.

Trenton native Sarah Coryell Shaw's diary is from the perspective of a more modern period (I940-195I). It chronicles her church and temperance activities in the St. Paul Methodist Church and the Hillcrest chapter of the WCTU.

Isaac Webster lived in Plainfield and Franklin Township; he was in the wagon- and carriage-making trade and a farmer. His diary (I852-I856) contains references to his temperance activity as a member of the Sons of Temperance at Plainfield.

Abram Bergen Wyckoff kept diaries while a student at Woodbridge Hall (I850-I85I) and later as an adult (1876-1879) in Mercer County. He was a member of the First Presbyterian Church in Hightstown and interested in temperance affairs. 
The above collections represent only a small fraction of Special Collections and University Archives' manuscript holdings. Within its wealth of personal papers, diaries, and organizational records are likely to be numerous references to temperance and liquor. It is easier to spot references to temperance in diaries and journals than to find them in voluminous family correspondence. Thus, there are likely to be numerous collections of family papers with such references. As collections are further described and cataloged, information about them will be more readily available. However, between the holdings of the Alcohol History Collection at the Center of Alcohol Studies and those in Special Collections and University Archives, Rutgers University is clearly an important place for people interested in the topic to conduct research. 